\title{
The protagonist's shadow and persona as the reflection of anti-hero in The Phantom of the Opera novel retold by Diane Namm
}

\author{
${ }^{1}$ Ratih Dwi Raharto* \& 2Riana Permatasari \\ ${ }^{1,2}$ College of Languages and Communication Science \\ Sultan Agung Islamic University \\ Semarang, Indonesia \\ *Corresponding Author \\ Email: ratihraharto@gmail.com
}

\begin{abstract}
Personality of any character in a work of art has become significant to be analyzed since it contributes to the value of the story. This paper analyzes a work concerning the personality of the protagonist. Unlike most protagonists who have the role to perform the traditional traits of a hero, some protagonists on the other hand tend to depict the characteristics of a villain. Yet the protagonist is still the leading character who just fails to enact the virtue of the society. In this case, a study of the concept of anti-hero is applied in order to expose the characteristics of anti-hero through the findings of the personality of the protagonist. The object of the study is a novel by Gaston Leroux retold by Namm (2008) entitled The Phantom of the Opera which has profound sense of psychological issues related to the characters inside the story especially the protagonist. This paper exerts a descriptive qualitative method and applies the psychology approach. Using two archetypes by Carl Gustav Jung, this paper focuses on two contradictory archetypes which are the persona and the shadow. For further analysis using the concept of anti-hero, this paper will use both archetypes to identify the characteristics of anti-hero. Henceforth, this paper discovered about the portrayal of those archetypes along with the reflection of anti-hero characteristics performed by the protagonist. There are two findings, first, the portrayal of the phantom's persona as the mysteriously creepy ghost to the society, Angel or Music to Christine and his shadow dealing with his crimes. Second, the characteristics of anti-hero used his persona and shadow to show that anti-hero is flouting the traditional hero virtue and gaining sympathy from reader even though his darker side is more dominant.
\end{abstract}

Keywords: Jungian psychoanalytic, the persona, the shadow, the concept of anti-hero

Received:

2 October 2018
Revised:

20 February 2019
Accepted:

28 February 2019
Published:

28 February 2019 
Raharto \& Permatasari, EduLite: Journal of English Education, Literature, and Culture Vol.4, No.1, February 2019, 65-75. DOI: http://dx.doi.org/10.30659/e.4.1.65-75

\section{INTRODUCTION}

In every work of art, the personality of the character cannot be separated from the psychology of both the writer and the reader. Powerful novels will be able to change the readers through the characters inside the story. In order to get better understanding about the story through the characters, an analysis of the character is needed to help the reader to perceive the conflict and get the message of the story.

Revelle \& Scherer (2017) state, "Personality is the coherent patterning of affect, behavior, cognition and desires (goals) over time and space,". As a part of what defines each individual to be different from one another, personality is the key point of what makes you yourself. According to Revelle and Scherer in their article entitled Personality and Emotion, the first to the third factors in 'coherent patterning' of what contribute to the personality such as 'affect', 'behavior' and 'cognition' come from the social life where people will be shaped according to norms and values in the society. However, the fourth factor which is 'desires'; it is a distinctive one because everyone must have his own 'desires' to accomplish something in life. If the connotation of 'desires' is interpreted as something which motivates individuals to reach their goals in life, would it be the same drive to provoke individuals for 'dark goals'.

Literature studies have many literary theories dealing with personality or we call it as psychoanalytic theory and one of them is introduced by Carl Gustav Jung in his theory about collective unconscious. As quoted in Garud's (2011) article,

To Jung, the third part of a person's psyche is the collective unconscious. As quoted by Sollod, Jung states that this collective unconscious is "detached from anything personal and is common to all men, since its contents can be found anywhere"; it contains images that are "flexible templates, or models, for current experience to follow", or "archetypes" (p.6).

The definition of collective unconscious represents archetypes or a person's psyche in order to define the difference from one man to another. Yet, it is not a personal matter because everybody can see the form of models. In the collective unconscious itself there are many archetypes such as persona, shadow and anima as cited from "A Handbook of Critical Approaches to Literature on Chapter 7 about Mythological and Archetypal Approaches" which states that,

One major contribution is Jung's theory of individuation as related to those archetypes designated as the shadow, the persona and the anima. Individuation is a psychological growing up, the process of discovering those aspects of one's self that make one an individual different from other members of the species (p.240).

To be able to break down a character's personality, psychoanalytic from Carl Gustav Jung with his persona and shadow archetypes can be applied, this study refers to the definition of the persona according to Fawkes (2014), Jung described the public face of the individual as the Persona, drawing on the Greek masks of ancient drama. Persona is a complicated system of relations between individual consciousness and society, a kind of mask designed to 'impress and conceal' and to meet societal demands (p.678).

The persona archetype gives clear border that the personality in a character is more likely to be concealed in order to fulfill the requirement of 
living in a social world. The things that people do in the society to get a good impression and to hide the bad side within are the mask.

The second archetype to be discussed here is the shadow archetype where, from the definition in a quotation, someone's personality is filled by something peculiar of 'shameful behaviors' and 'unacceptable aspects of the ego', (Levin, 1999). Someone who follows the model of shadow will tend to perform these manners which most people will not follow as it is typical of bad manners, while at the same time it is against their normal ego. It is most probably that shadow is the contrary of the persona. However, in someone's personality it is not impossible that a character can perform both archetypes.

Moving into a story's intrinsic elements about character, the protagonist acting as the center of the story should have performed a good characteristic so that their actions can be models for the readers to follow. This is also considered that the protagonist of the story reflect a hero characteristic. According to Roger D. Harms about a hero's characteristic, “... and since he must be a hero to someone, he must reflect the values of his society. The traditional hero must personify the socially accepted conventions, manner and values," (Harms, 1965). Therefore a good hero should be able to give good example, on the other hand, what about a hero who fails to give a good example as a traditional hero should be. A new term of anti-hero appears in order to solve the riddle of a 'bad-hero'.

The concept of "anti-hero" has been around a long time; it is usually referred to protagonists making questionable choices or committing crimes, while simultaneously clinging to their last shreds of humanity in order to save themselves or their loved ones (Drappa, 2016 ).

Therefore, even though the character in the story shows bad manners, he is still the protagonist of the story; with 'anti-hero' as the right term.

Related to the concept of anti-hero, an original novel by Leroux (1910) entitled The Phantom of the Opera retold by Namm (2008) has a thick characteristic of its gothic romance. The protagonist of the story represents a complicated personality and push readers to conclude whether he is a good or a bad character. Hence, this paper acquires the idea to analyze the main character's persona and shadow as a part of him in the story and even though he is the main character, his actions cannot perform a good heroic action. Instead, he performs the anti-hero concept.

Henceforth, a theory of psychoanalytic is suitable to be used to analyze The Phantom of the Opera especially in the protagonist's personality which is derived from the self within and the desires to be loved and accepted by someone even though he has flaws both shown in his face and his manners. The shadow and the persona archetypes will be revealed from the protagonist's personality and how it reflects the phantom's characteristics of anti-hero.

\section{RESULTS AND DISCUSSION}

The purpose of this study is to show the portrayal of the persona and the shadow archetypes of the protagonist reflected in the novel The Phantom of the Opera. The results of both archetypes are extended as the material to reveal the characteristics of anti-hero using the concept of anti-hero. 
Raharto \& Permatasari, EduLite: Journal of English Education, Literature, and Culture Vol.4, No.1, February 2019, 65-75. DOI: http://dx.doi.org/10.30659/e.4.1.65-75

\section{The persona and the shadow of the protagonist of the Phantom of the Opera \\ The Persona}

In accordance to the definition of the persona, based on Zhu \& Han (2013), theoretically, the persona shapes someone to enact a definite attitude which is not the authentic personality of that person but only visible by the eyes of the society. The sole intention of the persona is to acquire the requirements of living in the association; they also mention that this is a very fundamental equipment to survive in the social life (Zhu and Han, 2013). This theory can be pertained to the condition where the phantom of the opera is performing a rather dissimilar attitude when he deals with the person who is dear to him.

As the phantom of the opera house, he has been watching everyone in that opera house and his eyes are caught by a young lady named Christine Daae who is the back singer of the opera house. He has been approaching the girl as the Angel of Music where he teaches her how to sing. Now when the phantom talks to her secretly behind the mirrors and walls inside the opera house, the phantom continues the mysteriousness as the phantom of the opera but he speaks to her sweetly and gently. Taken from a dialogue in "The Phantom of the Opera" novel, it is quoted:

"I sing only for you," Christine said sadly. "Isn't that enough?" Her voice trembled with tears.

"You gave me a wonderful gift tonight, my dear. You sang beautifully," the voice said, (Namm, 2008).

While the phantom is known as the ghost who is eerie and mysterious, he has another personality whenever he deals with people he trusts. In other words, the phantom's persona from the society is in the contrary to the persona he wants to show to his beloved one. It is after the performance which the phantom asks Christine to sing in place of La Carlotta who is the lead singer in the opera house; she fears that she has not done well and worries if her song upsets the phantom. After that in Christine's room, she is talking to the phantom.

At that time, Christine tells him that she does what he asks her to do, in response; the phantom compliments how she has done a pleasing performance at that night. This action can be categorized into action of compassion which is a good character, here the persona that the phantom would like to perform is that he cares for Christine and he wants her to know by giving compliments. This second personality is used by the phantom because he feels comfortable to be kind and gentle only towards Christine. In the story, the phantom makes Christine believes that he is Angel of Music that her father used to tell her. So as the image of an angel, he adapts to the character and becomes as gentle and kind as possible toward her. In fact, the phantom is also using this persona to Christine because he wants to amaze her of how good he is as her Angel of Music, albeit he is actually pretending to cover his true being with his abnormal face.

The part when the phantom of the opera adjusts his way of treating Christine as she is his beloved person can be classified as the motive to his particular suitability. This scheme of behavior is well supported by Ann Hopwood in her article which says, "This is a part of the personality which comes into existence 'for reasons of adaptation or personal convenience,", (Hopwood, 3). 
Then related to the persona as the adjustment of the person with the surrounding in order to get what they desire, a quotation cited from Victor Daniels' paper saying, "It represents conscious ego with its many variations. It is the person's adaptation to the world; the manner he or she assumes in dealing with it. Must not be mistaken for whole person," (p.5). So not only being gentle and nice toward the people he trusts, the phantom also hides his other personality behind the persona. That true personality only emerges when the phantom is being pressured or feeling anxiety. As in the story where Christine is taken by force by the phantom into his hiding place, accidently she does something that enrages the phantom.

In this case related to the theory, the phantom performs his persona in dealing with the majority of people who are working in the opera house and the person who is important to him. For example, the first image that the phantom has is rather creepy because he wants everyone to be afraid of him. Then the second image of his persona is for Christine as the Angel of Music for her, he wants to show that he is kind and gentle. In spite of this, the truth reveals as Christine accidently discards his mask which he wears to cover his deformed face. So by the action, his true being appears and the phantom is just the same as a human but his personality that he wants to show to someone who is dear to him is different.

He can be sweet yet desperate at the same time. When his mask is torn off by Christine which results in the exposure of his ugly face, his insecurity arises so he becomes more aggressive and shouts at her. In the story, Christine is devastated by the terrifying image of the phantom yet she tries to remain calm and pretend that she is not disturbed by his face. The phantom then plays his instrument while pleading to be appreciated. The story shows that the phantom actually wants to be loved and to be accepted. By looking his deformed face, he is worried if Christine will no longer like him. His persona that he has built is on the verge of breaking so he cannot adapt to the situation between Christine and himself.

\section{The shadow}

"Judging by appearances: This story is about the great misfortune which can come to someone when they are different from everyone else, and when that person is not accepted for who they are," (The Phantom of The Opera Teacher's Note Level 5, 2008) will be the shadow of Erik because of this misfortune, a strong desire pushes Erik to do evil things in order to gain acceptance.

Talking about the shadow as one of the personality drive includes all obscure traits. According to Victor Daniels, if we try to identify our shadow, it comprises the gloomy features of character as current and genuine, because shadow makes one to commit the things that rational people will not do. This argument by Daniels is as well supported by Lindy Levin that, "The shadow is the container for shameful behaviors and unacceptable aspects of the ego," (Levin, 1999).

As the shadow carries the traits of cruelty, the phantom of the opera has accomplished several things related to disgraceful performance. In the story where the old managers of the opera house have retired from their jobs, the opera house throws party for them as well as a welcome party for the new 
Raharto \& Permatasari, EduLite: Journal of English Education, Literature, and Culture Vol.4, No.1, February 2019, 65-75. DOI: http://dx.doi.org/10.30659/e.4.1.65-75

managers. A day before the party there is an incident where the chief stagehand named Joseph Buquet is missing. He has had a terrible accident the day the new managers start to run the opera house. During the party where the old managers tell the new managers about the phantom of the opera, the new managers scoff and laugh it off. However, the phantom of the opera wants to give the same dreadful experience as he has done for the old managers, he shows up and threats the new managers directly. As quoted from the novel, "Gentlemen! Let the terrible tragedy of Joseph Buquet be a warning to you," the ghost said to the new managers, (Namm, 2008). From the dialogue that the phantom mentions, the phantom has caused the death of Joseph Buquet. He also warns the new managers to be careful in the future. This action is an unacceptable aspect of ego where taking someone's life is the matter. If he is following the normal ego, he just needs to appear and warn the new managers without harming anyone. So he is just being selfish and kills someone innocent to make his threat stronger.

Not only relating his awful crimes to the people at the opera house but also Raoul who have been seeing Christine, the girl that the phantom desires, gets the effects. It is when Raoul knows that his childhood love, Christine is behaving strangely as if she pretends she does not remember him. So he needs to find out the reason of her behavior. Later, Christine tells Raoul that her father has sent the Angel of Music at the opera house which is the phantom. However, Raoul cannot accept that, he convinces Christine that Angel of Music is just a fairy tale and it is not real. Christine turns away as she does not want to listen to Raoul.

The phantom on the other hand has been following Christine and he watches everything that Raoul does and tells her. In the story, the phantom does awful thing as he is conquered by his shadow, "The moonlight revealed the shadow's head. The last thing Raoul remembered seeing was a snarling face and a pair of scorching eyes. The inn keeper found Raoul the next morning. He lay half-frozen upon the inn's steps," (Namm, 2008). The phantom feels that Raoul can be a threat to his way with Christine, so one night when Raoul loses track of Christine, the phantom is stalking him and hits him in the head leaving the man unconscious. He does so because he needs to get rid of the person who is going to take Christine away from him. His selfish desire to get Christine for himself pushes him to hit someone almost to death.

The phantom who has known the opera house like a piece of cake plans to protect himself from the people whose intention to reveal his true identity. Therefore he makes several traps on the way to his hideout. Not only dangerous, the traps and tricks that he sets are also deathly. In order to protect himself, he turns to be a villain who has intention to kill intruders and this is an action done because of the animalistic threat in order to alleviate his territory. As mentioned from the story:

"We cannot enter his house from the lake," the Foreign Stranger said. "He uses a trick to guard the lake. He sings his enchanting songs through a reed pipe under the water. People who enter the lake can't resist his song. They follow the sound underwater and drown, (Namm, 2008).

Consequently the action of killing anyone who has trespassed his territory is included into the act of human's animal feature as mentioned by Zhu and Han (2013) that it is shadow which influence one to act so 
dangerously related to the disruption of comfort zone. It is also as a result of the contrary to the ego. In an instant, someone who has rational ego will investigate people who try to come into their comfort zone instead of killing them straight on place.

Another incident related to the shadow is when Erik tries to deal with an intruder who comes into his territory so Erik uses one of his tricks to make anyone who enters the lake to be drowned by his enchanting song. Eventually, it is found that the guest that the phantom refers to is Count Philippe, Raoul's older brother. Even though in other word he kills someone, the quotation shows that Erik shows no guilty feeling. As he mentions that, "In memory of the fellow I met in the lake. He should not have come looking for me. He will never come looking for me or anyone else again," (Namm, 2008).

\section{The reflection of anti-hero portrayed by the protagonist of the Phantom of the Opera}

There are two characteristics of anti-hero that are performed by Erik throughout the story from both his persona and shadow. The first characteristic is when Erik fails to portray the virtue of traditional hero. One says that, "If we only scratch the surface of this character type, the antihero is a character that rejects traditional modes of heroic selflessness in favor of very un-heroic selfishness. To put another way, the simplest definition of an antihero is a "bad" hero," (White, 2013). In accordance to the reference of how anti-hero character will reject all good forms, Erik in the story shows these 'un-heroic selfishness'.

For example, the phantom is known to be criminals which commonly done by the villains. The Foreign Stranger tries to tell Raoul what is the life of Erik looks like before he settles in the opera house. In a dialogue between them, The Foreign Stranger mentions that the things done by Erik are mostly crimes and due to his criminality, he escapes from the previous country to build a hiding place so that he will be safe from those who chase after him. The history of Erik shows that he is more like a villain instead of hero and so the right call for him is anti-hero. "He escaped from my country and became a builder in this one. He built the opera house to be his secret hiding place. He committed many terrible crimes in my country," (Namm, 2008).

Angelica Drappa also states in her paper that anti-hero character will seem like the villain due to their problematic actions, "The concept of "antihero" has been around a long time; it is usually referred to protagonists making questionable choices or committing crimes," (Drappa, 2016). For example in the story where the phantom kidnaps Christine, he puts her in the position to bring danger to the people around them or she can choose to love the phantom so that the people can be saved.

"Silence! Or I will blow everything up!" Erik said in a cold, dead voice.

"The choice is up to you. If you turn the grasshopper, we will all be blown up, along with a whole quarter of Paris. If you turn the scorpion, to celebrate our wedding, all the gunpowder will be soaked and drowned. Only you can save the people of Paris. And then we can be happily married!" (Namm, 2008).

Conquered by his anxiety, the phantom intimidates Christine that he will put everyone in danger if Christine chooses to leave him. It is a typical of antihero characteristic to commit crime instead of holding justice. Anxiety is 
Raharto \& Permatasari, EduLite: Journal of English Education, Literature, and Culture Vol.4, No.1, February 2019, 65-75. DOI: http://dx.doi.org/10.30659/e.4.1.65-75

caused by the condition where something maddening happens to someone so that he cannot achieve his goal (Nurtjahyo, 2016), by this the phantom is pushed to commit something terrible so that he can still get his wish. The previous quotation by Jeremy White (2013) also supports the fact that the phantom as he is the anti-hero character, he violates the manner of good hero, instead his humanity is shredded because of his desire to get the girl he loves.

Another example that shows the phantom breaks the trait of traditional hero is by deceiving. There is time in the story where Raoul figures out about the man who has been approaching Christine behind the walls of the opera house to be the phantom of the opera. Even though Christine tells him that the voice she has been listening to is her Angel of Music, Raoul will not believe it. As he hears news that the phantom of the opera has been causing many awful things in the opera house, Raoul believes that the phantom is the same person as Christine's Angel of Music. The phantom as the protagonist of the story fails to perform the characteristic of the traditional hero where the moral value is flawed by his action. In the contrary, as the reference of the anti-hero mentions, he tends to perform the traits of a villain where he commits crimes and terrors to the society.

Then another example of the characteristic of anti-hero dealing with rejecting the value of traditional hero which is performed by Erik in the story is murder. One mentions that, "Indeed, although the formula used for the anti-hero is mostly the same, that is, that of morally flawed protagonists committing serious crimes, with murder being the one they usually have in common (Vaage 2015, 1)," (qtd. in Drappa, 2016).

In the story, the phantom has done many crimes and some of them including taking other people's lives. It is when the phantom of the opera is very protective about his private life so he has built his hideout that nobody will be able to pass. In the story where Christine is kidnapped the second time, the phantom is trapping both Raoul and The Foreign Stranger after he says that he will 'welcome' the guest to his lake. His intention of welcoming is never the literal meaning but because he needs to get rid of the person who is trying to pass his lake which will lead to his home. "In memory of the fellow I met in the lake. He should not have come looking for me. He will never come looking for me or anyone else again," (Namm, 2008).

As the main character of the story where he should show more humanity value, the phantom chooses to maintain his way of treating people around them by killing them straight. As mentioned in the previous reference that one trait of anti-hero is committing crimes where murder is the common among the crimes, this point is as a prove that he is performing the concept of antihero through his shadow which is murder in order to prevent anyone in unveiling the truth of the phantom of the opera.

The second characteristic of anti-hero according to the definition of antihero is gaining sympathy because he is surrounded by unfortunate fates. In this case, the phantom that uses persona to cover his face cannot freely live like a normal person because his face is deformed and it is also why he wants to be loved because since he was born nobody has ever wanted to look at him. This will create the feeling of sympathy from the reader. It is not his fault to be born with flaws on his face but the society is being cruel by not accepting him. This trait is one of the characteristics of anti-hero. As mentioned that, "Anti- 
hero is a slippery term that can cause a lot of confusion. Simply stated, an Anti-hero is not the opposite of a Hero, but a specialized kind of Hero, one who may be an outlaw or a villain form the point of view of society, but with whom the audience is basically is sympathy." (Vogler 1998, 34)," (Drappa, 2016).

"Now that you have torn off my mask, you can never leave!' he told me." Christine trembled at the memory.

"How did you escape?" Raoul asked.

"I pretended he did not scare me. I listened to him play his music on a grand organ. He sobbed and begged me to love him. I felt sorry for him and promised to return. Erik believed me. Then he gave me this gold ring. He said as long as I wore it, you would be safe from harm," (Namm, 2008).

The phantom who loves Christine blindly wants to keep her for himself so he does every cruel things even though they might hurt her, he still becomes the bad guy. In the story, the phantom lets go of Christine from his capture on one condition, to wear the gold ring so whoever sees it will not approach her. Even though his actions are wrong, the reason that pushes him to do so is quite heart-sinking, it is to be loved. The feeling of the reader toward the phantom will start to stagger either to hate or pity him. From this point, the sympathy toward this character arises.

The persona of Erik is known to be someone so wicked and also a killer yet it is not merely because he is a real villain but there is a reason behind. In the quotation of the story, Raoul and The Foreign Stanger are trapped by Erik in mirror room where they cannot escape and they will die from his many murderous tricks. Meanwhile society takes Erik as a villain in the representation of Raoul, The Foreign Stranger succeeds to bring plays with the reader's perspective on why Erik has suffered this whole time and that what he has done is a result of his miserable past.

"You and Christine both pity this creature. I have seen it in your eyes," Raoul said. "Why?"

"Erik's own mother would turn her head away and make him wear a mask. She never once kissed him, or held him close.

"Erik has been trated badly by this world. You ask me why I pity him. I ask you, how can I not?" (Namm, 2008).

So we can value that a characteristic of anti-hero gives prove to the reader that the villainy of Erik worth a sympathy.

After the incident where Raoul, The Foreign Stranger and Christine are trapped in Erik's hideout below the opera house, the three of them get caught by the phantom and the next morning The Foreign Stranger is already in his apartment. When Erik comes into his room, The Foreign Stranger asks him about Raoul and Christine but Erik just sits there and tells him about what happens to Christine. He tells The Foreign Stranger that he has released Christine because she shows him true compassion and he feels so happy as well as so sad because he knows that keeping Christine by his side will not make her happy.

"When I returned, Christine was waiting for me as she had promised. I tore off my mask. She did not run away. Then, she kissed me on the cheek and said, 'Poor Erik!' At that moment, I felt all the happiness in the world!" Erik sobbed.

"She asked me in a soft voice why I was letting her go. How could I explain it? Christine was the only one who had ever shown me kindness. She didn't run when she saw my horrible face. She had looked past my mask 
Raharto \& Permatasari, EduLite: Journal of English Education, Literature, and Culture Vol.4, No.1, February 2019, 65-75. DOI: http://dx.doi.org/10.30659/e.4.1.65-75

and into my heart. She deserved to be happy and free. But without her, I can never be either," Erik said, his voice full of sadness, (Namm, 2008).

This is the climax of the story where the phantom learns about love and sacrifice. He has done many horrible crimes and yet Christine still shows him kindness and he saves her from the vulnerable life with the phantom and in the end not only gaining comprehension from the readers, the phantom also shows one more of the concept of anti-hero as referenced from Angelica Drappa mentioning that he will maintain his human side and unbound the girl he loves to be happy with her own choice. As cited that, "The concept of "anti-hero" has been around a long time; it is usually referred to protagonists making questionable choices or committing crimes, while simultaneously clinging to their last shreds of humanity in order to save themselves or their loved ones," (Drappa, 2016).

\section{CONCLUSION}

In conclusion, there are two persona that the phantom performs which are in front of the society as the ghost and in front of the girl he loves as her Angel of Music. Both differ in treatment and purpose. To the adjustment of dwelling in the opera house as the phantom of the opera, the phantom hides his identity as the mysterious and tricky phantom. In the contrary, to get the love of his girl, the phantom has deceived the girl as a sweet and caring angel. The entire persona is built in order to hide his horrible face that has been with him since he was born. The exposure of his true being as a guy who has a deformed face leads to the breakdown of his persona.

The shadow on the other hand emerges when the phantom is cornered so he leans on his darker sides of personality which pilots him to enact many nasty crimes. The actions done by the phantom is the form of defense so he will not be hurt. Although he has done many crimes before he has built and settled in the opera house, his crimes become more serious as he has more power in the opera house. Starting from the murder of Joseph Buquet, then the stealing and sabotaging inside the opera house, then another kill of Count Phillipe to the disastrous plan to blow the opera house and some part of the town, the phantom uses all his tricky and deathly ideas to stay secured and get what he wants; Christine.

The persona and the shadow of the phantom portray the concept of antihero where he denies the traits of traditional hero or a good hero. The persona of the phantom violates the traditional hero as a mischief and selfish person while he also underlines the traits of a villain through his shadow related to stealing, kidnapping, torturing and killing. Albeit his evil deed, the concept of anti-hero reveals the trait where no matter how bad he may be, the readers tend to be more sympathetic toward the phantom because of his background and reason.

The story of Erik teaches reader that it is hard to pretend to be someone else. His persona is done in order to meet the societal demand where he has been taking the mask of the phantom so he can adapt and survive from the judgment of the society about his abnormal face if they ever see it. While at the same time, to be able to love someone doesn't always make you feel happy. Yet, to be kind and to love sincerely is a matter of choice. Sometimes sacrifice needs to be made in order to keep someone dear to us to be happy. 


\section{REFERENCES}

Daniels, V. (2011). The analytical psychology of Carl Gustav Jung: 1-13. Web. 20 Dec. 2017.

Drappa, A. (2016). The Visual Representation of The Anti-Hero In Quality TV Case Studies: Breaking Bad, Mad Men and Sons Of Anarchy. Faculty of Arts, Redboud University: 1-87. Web. 9 June 2017.

Fawkes, J. (2014). Perfomance and Persona: Goffman and Jung's approaches to professional identity applied to public relations. Public Relations Review 41: 675-680. Web. 27 May 2017.

Garud, M. (2011). A Jungian Analysis of Coraline. Psychology X175 Theories of Personality. Web. 27 May 2017.

Harms, R.D. (1965). The Development of The Anti-Hero in The American Novel: 1883-1962. The Department of English and The Graduate Counsil Kansas State Teachers College of Emporia. Web. 6 June 2017.

Hopwood, A. Jung's model of the psyche. Web. 20 Dec 2017.

Levin, L. (2017) Shadow Into Light: A Jungian Analysis of The Night of Iguana. The Tennessee Williams Annual Review, Web. 27 May 2017.

Mythological and Archetypal Approaches. A Handbook of Critical Approaches to Literature. Web. 27 May 2017.

Namm, D. (2008). The Phantom of The Opera. New York: Sterling Children's Book. Print.

Nurtjahyo, G. (2016). The Anna Leonowens' Anxieties and Ego Defense Mechanisms as Found in Elizabeth Hand's Anna and The King: a Freudian Psychoanalytical Approach. Edulite: Journal of English Education, Literature and Culture Vol. 1, No. 1 DOI: http://dx.doi.org/10.30659/e.1.1.17-27.

Revelle, W. \& Scherer, K.R. (2017). Personality and Emotion.Oxford Companion to The Affective Sciences. Oxford UP, n.d. Web. 9 April 2017.

The Phantom of The Opera - Teacher's Note Level 5. (2008). Pearson Education Limited: 1-5. Web. 10 April 2016.

White, J. W.. (2013). "The Anti-Hero as Social Critic: Two Original Scripts". A Dissertation in Fine Arts - Theater. Web. 9 June 2017.

Zhu, J. \& Han, L. (2013). Analysis on the Personality of Maggie By Jung's Archetype Theory. Theory and Practice in Language Studies 3.2: 324-328. Finland: Academy Publisher. Web. 27 May 2017. 